Submit 2020-11-30 | Revisions Required 2021-03-22 | Revisions Required 202106-04 | Accept Submission 2021-06-09

\title{
STRATEGIES OF CAREER WOMEN AT ISLAMIC UNIVERSITIES IN KALIMANTAN IN CARRYING OUT HOUSEHOLD OBLIGATIONS FROM THE PERSPECTIVE OF MAQASHID AS-SYARI'AH
}

\author{
Norcahyono \\ Family Law Study Program, Faculty of Islamic Studies \\ Universitas Muhammadiyah Palangkaraya \\ norcahyono.arribangi@gmail.com \\ M. Arni \\ Islamic Education Study Program, Faculty of Islamic Studies \\ Universitas Muhammadiyah Palangkaraya \\ arni@gmail.com
}

\begin{abstract}
The problem of this research is the dual role of female officials (hereinafter referred to as "career women") at Islamic universities in Kalimantan. The reasons for the research are (1) Knowing the constraints of the role played by career women at Islamic universities in Kalimantan in carrying out their obligations as housewives. (2) Revealing the role strategy of career women at Islamic universities in Kalimantan in carrying out household obligations from the Maqashid Syari'ah perspective. This research method is descriptive analytical with a normative approach. The results of the study are (1) The obstacles for career women in carrying out their obligations as housewives are not having enough productive time at home, feeling beyond their capabilities by playing multiple roles, and feeling tired. (2) The role strategy that is carried out to complete household obligations is carried out by adopting students, preparing household assistants, asking for help from family or other people, and cooperating with husbands. It can be concluded that in the perspective of Maqashid Syari'ah, the role strategy carried out by female officials in completing household obligations belongs to the Maqashid al-Hajiyyah level, namely the efforts made by career women to eliminate their difficulties in carrying out household obligations assigned to them to be the responsibility together in the family.
\end{abstract}

Keywords: Multiple roles, career woman, maqashid as-Syari'ah 


\section{INTRODUCTION}

Being a career woman is not forbidden in Islam. This means that women can work in the public space, as long as the work carried out is in accordance with their character, specialization, and ability and does not damage their degree of honor. This ability is based on the consideration that the woman or her family needs her to work, or at the same time, the community does need her expertise. ${ }^{1}$

According to Nasaruddin Umar, in the Al-Qur'an and Hadith, there is no explicit prohibition for women to work, whether the profession is done individually or collectively, whether in government or private institutions, as long as the work is lawful and carried out in a respectful atmosphere, and prevents things that can cause fade. ${ }^{2}$

Islam through the oral of its Prophet provides guidance that there is a need for a division of roles in household management between

${ }^{1}$ Yusuf al-Qardhawi, "Markazul mar'ati fil Hayah al-Islamiyah", terj. Muh. Suri Sudahri A. and Entin Rani'ah Ramelan, Jakarta, Pustaka al-Kautsar, (1996): 239

2 Nasaruddin Umar, "Fikih Wanita Untuk Semua", Jakarta, cet. 1, PT Serambi Ilmu Semesta (2010): 150 husband and wife. Rasulullah said:

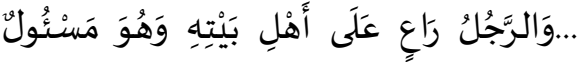

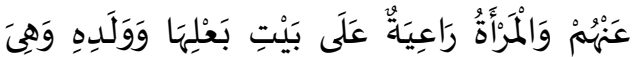

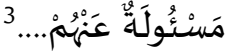
members and will be beld accountable for them, a wife is the leader in the affairs of her busband's household and towards his children and will be held accountable for them...

Based on the information from the hadith, Islam calls for women to take care of their husband's household affairs and take care of their children. However, in practice, during the time of the Prophet, women also played an active role in building civilization and carrying out socio-economic activities. Among them were the Prophet's Wives. Khadijah was a tough columnist who successfully ran the export and import business. Safiyah bint Huyay was a bridal make-up and Zainab bint Jahsy worked in the home industry by tanning animal skins.

Other women were like Qilat Ummi Bani Ammar who once came to the Prophet to ask for directions on

3 Muslim, al-Jaami' as-Shabih al-Muslim Shabih Muslim, Juz. 6, Bairut: Daar al-Afaaq alJadidah, (t.tt): 7 
the matter of buying and selling. Raithah, the wife of Abdullah Ibnu Mas'ud, was a businesswoman and was able to suffice her family. Also, as-Syifa was a woman assigned by Umar to take care of the market in the city of Medina. ${ }^{4}$

According to the Great Indonesian Dictionary, the term "career woman" means adult women who are engaged in professional activities (business, offices, etc.). ${ }^{5}$ In English, the term "career" means "A job or profession for which one is trained and which one intends to follow for part or whole of one's life", or "a job or profession especially one with opportunities for progress". Based on the meaning that the authors have mentioned, "career woman" is a woman who takes part in the professional field as well as in the field of expertise that is owned and carried out seriously in order to develop her own competence to be more advanced and professional.

Currently, the awareness of women being equal with men is increasing. Many women have taken part in

\footnotetext{
${ }^{4}$ Ibid, Nasaruddin Umar: 148

5 Depdikbud, "Kamus Besar Bahasa Indinesia”, Gramedia Pustaka Utama, Jakarta, cet.1, edisi 4, (2008): 372
}

public life which has been dominated by men all this time. Many women work outside the home, and many of them become career women. However, the involvement of women in the public sphere inevitably creates new problems, especially in the domestic sphere of the household.

According to Adnan, the negative impacts of career women have bad influences on individuals and society, ${ }^{6}$ among them are:

1. The neglect of the mother's role in providing love and education to children.

2. Gathering with men who are not mahram and can endanger their honor, morals, and religion.

3. Conducting dishonorable behavior such as grooming and making up excessively to invite slander and attract the attention of men.

4. A woman who works outside the home has left her nature as a mother of children and a mother who manages her husband's household.

5. Excessive dress and decoration like

\footnotetext{
6 Adnan bin Dhaifullah Alu asySyawabikah, "Wanita Karier: Profesi Di Ruang Publik Yang Boleh Dan Yang Dilarang Dalam Fiqih Islam", terj: Zulfan, Jakarta: Pustaka Imam Asy-Syafi'i, (2010): 114-115.
} 
loving gold jewelry that may cost a lot of money than the material obtained.

The division of roles in the household based on the guidance of the Prophet does not prevent women at that time from carrying out work outside the home. The problem now is that women who work as career women have negative impacts on themselves in the form of fatigue which then results in the neglect of work at home because no one is responsible. In the perspective of maqashid as-Syari'ah, the implementation of household affairs such as housing and children's education is an important matter that must be fulfilled and carried out. If it is not fulfilled and implemented, it can trigger a conflict between husband and wife which can threaten the peace and comfort of the family members.

As for what is meant by Maqashid as-Syari'ah are the objectives that become the cause for the stipulation of syara' law in order to realize the benefit for humans. ${ }^{7}$ Maqashid as-Syari'ah are very close with wisdom,

\footnotetext{
7 Ahmad al-Rasyuni, "Nadhariyah alMaqashid I'nda al-Imam al-Syathibi", Virginia: The Internasional Institute of Islamic Thought (1995): 19
}

illat, goal or intention, and benefit. ${ }^{8}$ According to the ulama' ushul, Maqashid as-Syari'ab are the final goals that must be realized by the implementation of Islamic Syari'ah. This is in line with the definition of Maqashid as-Syariah stated by Yusuf Hamid al-'Alim, namely; the goals that the syari'ah wants to achieve are the benefits that return to the people, both in the life of the World and the Hereafter, whether the realization is through efforts to achieve the benefits or in the context of efforts to reject the harm or loss. ${ }^{?}$

Imam as Syathibi divides Maqashid as-Syari'ah into the five main elements, namely (1) Hifdru ad-Din (protecting the Religion), (2) Hifdzu an-Nafs (protecting the soul), (3) Hifdzu al'Aql (protecting the mind), (4) Hifdru al-Mal (protecting the property), and (5) Hifdzu an-Nasl (protecting the offspring). In realizing and maintaining the five main elements, as-Syathibi again divides them into three levels according to the level of importance and benefit. The three

\footnotetext{
8 Ahmad Imam Mawardi, "Fiqh Minoritas Fiqh al-Aqalliyat dan Evolusi Maqashid as-Syari'ah dari Konsep ke Pendekatan", Yogyakarta:LKiS, (2000): 180
} 
interests referred to are (1) Level of Dharuriyat needs, namely the needs that must be met. If it is not fulfilled, it will make life become damaged. (2) Level of Hajiyat needs, namely the needs that should be fulfilled. If it is not fulfilled, it will result in difficulties.

(3) Level of Tabsiniyat need, namely the complementary needs. If it is not fulfilled, it will make life uncomfortable. $^{10}$

Based on the above problems, the authors are interested in examining the problems experienced by the career women at Islamic universities in Kalimantan in carrying out the household obligations on the sidelines of their busy status as female officials. Through this article, the authors present the results of research to reveal the constraints and strategies of career women at Islamic universities in Kalimantan from the perspective of Maqashid as-Syari'ah. The results of this study are expected to provide information as well as a solution for career women wherever they are in order to minimize the problems they experience in carrying out their

${ }^{9}$ Ibid, Ahmad Imam Mawardi: 183

${ }_{10}$ Ibid, Ahmad al-Rasyuni, Nadhariyah..., hlm. 21 obligations in the household.

\section{METHOD}

This study takes the form of field research, as for that the nature of the research is Descriptive Analysis. The objects of the research are female officials at Islamic universities in Kalimantan. The approach used in this research is the normative approach which is used to see whether there is a match between the data obtained from the research results with the norms of Islamic law.

Data collection is conducted in the ways of interview, documentation, and observation. The next step is to analyze it using the induction method so that it allows the research findings to emerge from the general situation.

\section{RESULTS AND DISCUSSION}

This study succeeded in extracting data from 20 career women respondents who have positions at 11 Islamic universities in Kalimantan. The Islamic Universities in Kalimantan that were successfully sampled in this study were 2 Islamic Universities in Central Kalimantan, 7 
93 I Norcahyono, Arni, Strategies of Career Women at Islamic Universities..., pp. 88 - 102

Islamic Universities in South authors describe the results of the Kalimantan, 1 Islamic University in research which are considered to

West Kalimantan, and 1 Islamic answer the research problem in the form of a concise table:

\begin{tabular}{|c|c|c|c|c|}
\hline No. & Respondents & $\begin{array}{l}\text { Position at } \\
\text { Higher } \\
\text { Education }\end{array}$ & $\begin{array}{c}\text { Constraints in } \\
\text { Organizing and } \\
\text { Managing Household } \\
\text { Needs }\end{array}$ & $\begin{array}{l}\text { Strategies in Organizing and } \\
\text { Managing Household Needs }\end{array}$ \\
\hline 1 & $\begin{array}{l}\text { University of } \\
\text { Muhammadiyah } \\
\text { Palangkaraya } \\
\text { (Central } \\
\text { Kalimantan) }\end{array}$ & $\begin{array}{l}\text { Vice } \\
\text { Chancellor }\end{array}$ & - Very inconvenient & $\begin{array}{l}\text { - Asking for help from other } \\
\text { people, namely foster children } \\
\text { from among students funded for } \\
\text { their college education. They } \\
\text { take turns carrying out the } \\
\text { duties, some are in charge of } \\
\text { taking care and teaching iqro' } \\
\text { and school lessons, some are } \\
\text { taking care of the clothes, } \\
\text { washing, and some are in charge } \\
\text { of cleaning the room. }\end{array}$ \\
\hline 2 & $\begin{array}{l}\text { Islamic Institute of } \\
\text { Darussalam } \\
\text { Martapura. (South } \\
\text { Kalimantan) }\end{array}$ & Dean & $\begin{array}{l}\text { - Quite a hassle and } \\
\text { inevitably had to be done } \\
\text { - The time available for } \\
\text { doing the housework is } \\
\text { not enough and the work } \\
\text { is always endless. }\end{array}$ & $\begin{array}{l}\text { As much as possible the } \\
\text { housework should not pile up. } \\
\text { To finish them, getting up early } \\
\text { is necessary. }\end{array}$ \\
\hline 3 & $\begin{array}{l}\text { Postgraduate } \\
\text { Program at UIN } \\
\text { Antasari } \\
\text { Banjarmasin. } \\
\text { (South } \\
\text { Kalimantan) }\end{array}$ & $\begin{array}{l}\text { Head of } \\
\text { Study } \\
\text { Program }\end{array}$ & $\begin{array}{l}\text { - Quite a hassle for doing } \\
\text { dual roles } \\
\text { - Not quite optimal in } \\
\text { playing the roles as a wife } \\
\text { and a mother of children }\end{array}$ & $\begin{array}{l}\text { - Housework is assisted by other } \\
\text { people, and sometimes it is done } \\
\text { alone by getting up early. } \\
\text { - Having a household assistant }\end{array}$ \\
\hline 4 & $\begin{array}{l}\text { IAI Sultan } \\
\text { Muhammad } \\
\text { Syafi'uddin Sambas } \\
\text { (West Kalimantan) }\end{array}$ & $\begin{array}{l}\text { Chairman of } \\
\text { the Lab }\end{array}$ & $\begin{array}{l}\text { - } \quad \text { Quite a hassle } \\
\text { - The time available for } \\
\text { doing the housework is } \\
\text { short if it must be divided } \\
\text { by office work. }\end{array}$ & $\begin{array}{l}\text { - Getting up early and getting help } \\
\text { from the husband in completing } \\
\text { the housework. } \\
\text { - Having a commitment with the } \\
\text { husband about the risks if the } \\
\text { wife works outside the home }\end{array}$ \\
\hline 5 & $\begin{array}{l}\text { IAI Sultan } \\
\text { Muhammad } \\
\text { Syafi'uddin Sambas } \\
30\end{array}$ & $\begin{array}{l}\text { Secretary of } \\
\text { Study } \\
\text { Program }\end{array}$ & - Tired of doing housework & - Asking for help from the family \\
\hline 6 & $\begin{array}{l}\text { IAIN Palangka } \\
\text { Raya. (Central } \\
\text { Kalimantan) }\end{array}$ & $\begin{array}{l}\text { ASN/State } \\
\text { Civil } \\
\text { Apparatus }\end{array}$ & $\begin{array}{l}\text { - It's quite a hassle and it's } \\
\text { difficult to manage the } \\
\text { time to balance work time } \\
\text { and housework }\end{array}$ & $\begin{array}{l}\text { - Housework is not always done } \\
\text { alone, it is sometimes assisted by } \\
\text { a family. } \\
\text { - Accustoming children to be } \\
\text { independent and responsible } \\
\text { with housework. } \\
\text { - Doing it alone by getting up } \\
\text { early }\end{array}$ \\
\hline 7 & $\begin{array}{l}\text { STAI Al-Falah } \\
\text { Banjar Baru (South } \\
\text { Kalimantan) }\end{array}$ & Lecturer & $\begin{array}{l}\text { - Still having small children } \\
\text { - } \begin{array}{l}\text { Housework is often } \\
\text { neglected. }\end{array}\end{array}$ & $\begin{array}{l}\text { - Taking advantage of the time } \\
\text { - Waking up earlier. }\end{array}$ \\
\hline
\end{tabular}




\begin{tabular}{|c|c|c|c|c|}
\hline 8 & $\begin{array}{l}\text { STIT Balikpapan } \\
\text { (East Kalimantan) }\end{array}$ & $\begin{array}{l}\text { Assistant/ } \\
\text { deputy } \\
\text { chairman }\end{array}$ & - Housework is endless. & $\begin{array}{l}\text { - Cooperating with husband and } \\
\text { children } \\
\text { - Teaching children that } \\
\text { housework is a shared } \\
\text { responsibility. }\end{array}$ \\
\hline 9 & $\begin{array}{l}\text { University of } \\
\text { Muhammadiyah } \\
\text { Palangkaraya } \\
\text { (Central } \\
\text { Kalimantan) }\end{array}$ & $\begin{array}{l}\text { Head of } \\
\text { Division/ } \\
\text { Section }\end{array}$ & $\begin{array}{l}\text { - Quite a hassle } \\
\text { - Time at home is less when } \\
\text { compared to the } \\
\text { obligations that must be } \\
\text { completed }\end{array}$ & $\begin{array}{l}\text { - Housework is not always done } \\
\text { alone, it is sometimes assisted by } \\
\text { the husband } \\
\text { - Managing time and sharing roles } \\
\text { with the husband }\end{array}$ \\
\hline
\end{tabular}

1. Constraints of Career Women at Islamic Universities in

\section{Kalimantan in Carrying Out}

\section{Household Obligations}

Many women today play a dual role in the family, even play a multifunctional role because they have had the widest opportunity to develop themselves outside the home. Currently, many women hold positions and become important people in society, who are no longer monopolized by men. The important role of women will certainly have an impact on the joints of social life, both positive and negative. ${ }^{11}$

Based on the research data, the main constraints for career women at Islamic universities in Kalimantan in organizing and managing their households are (1) having difficulty dividing their time between

${ }^{11}$ Nova Yanti Maleha, "Pandangan Islam Tentang Pilihan Hidup Wanita Karir", $A n$ Nisa'a: Jurnal Kajian Gender dan Anak, Volume 13, Nomor 01, Juni (2018): 106 housework and career women jobs, (2) experiencing fatigue when having to do the housework, and (3) causing the ineffectiveness in playing the roles as a wife and a mother of the children.

The existence of constraints for a woman in carrying out household duties is a negative impact due to her role as a career woman. This constraint is found because the woman plays a dual role in the family.

Based on the research results of Nurlaila and Yolanda Mohunggo ${ }^{12}$, among the impacts of the dual roles experienced by women in the family are:

First: Difficulty in dividing time between family obligations and work obligations.

Second: The potential for misunderstanding with husbands and other family members.

12 Nurlaila and Yolanda Muhunggo, "Persepsi Wanita Karier Terhadap Konflik Pekerjaan dan Keluarga", Jurnal Management Sinergi, Nov 9;1 (2017): 10 
Third: Some housework have to be done by other people.

Fourth: The physical and spiritual needs of the children are not being met.

Fifth: There are fears of cracking in the household.

Yusuf al-Qardhawi, one of the modern Islamic scholars, revealed some of the dangers or negative impacts of a woman working in public spaces, including:

First: The danger for the woman herself, because she has exceeded her duties as a woman with her dual role, or does not carry out the works in her household because of her busy life outside the home.

Second: Danger for her husband, because she is not optimal and in totality to fulfill her obligations as a wife due to her busy work. It creates the opportunity for her to underestimate and feel more capable than the husband in terms of knowledge and finances because she has a better job than her husband.

Third: Danger for the children, because her busy life as a mother outside the home is exhausting and it makes her not optimal in raising and educating the children. ${ }^{13}$

Based on the explanation above, there are several negative impacts if career women carry out dual roles in the family. Especially if the career women prioritize public roles rather than carrying out household affairs and meeting the needs of family members.

Generally, career women feel guilty and sad because they are unable to allocate time in carrying out their duties at work as well as carrying out obligations in the household. A survey states that $53 \%$ of career women complain about the burdens they have to bear in the morning to evening at work, while at night the rest of their productive time carries out household obligations. Even from the results of Najat Abdullah's research in his dissertation, $73 \%$ of career women spend six to eight hours of their productive time outside the home, and this is one reason that causes various psychological problems for children. ${ }^{14}$

The constraints experienced by career women at Islamic Universities

${ }^{13}$ Ibid, Yusuf al-Qardhawi: 235

14 Muhammad bin 'Abdullah al-Habdan, Dzulmul Mar-ah, Terj. Yunus, "Melawan 
in Kalimantan in carrying out household obligations are common problems experienced by career women who play dual roles in the family. The main factors that cause the implementation of obligations in the house not optimal are their busyness as officials at work, fatigue after arriving home, and the lack of productive time that can be used when they arrive home.

At the time of the Prophet Muhammad, the women sent messengers to the Prophet Muhammad to protest their situation in the family. According to women, at that time men were given several virtues to be able to play roles in the public domain which were not given to women. The female envoy was Asma' Binti Yazid. Asma' came to the Prophet's assembly and said: "O Allah's Messenger, I am the messenger of the women to be the representative facing you. Indeed, Allah has sent you to women as you were sent to men. Women sit in the household (busband), we (wife) cook food for our husband, and we satisfy our husband's lust. Sometimes the husband leaves the house for

Kedzaliman Terhadap Wanita”, Jakarta: Pustaka Imam Syafi'i, Cet. Pertama (2004): 92 traveling, goes on pilgrimage, or does jihad. So it is the wife who lives and looks after the husband's household, it is the wife who looks after the husband's property, and it is the wife who educates the husband's children. Then the husband exaggerates the wife. The busband goes to Friday prayers, goes to pray in congregation, and goes to fight for jibad fi sabilillah. Then what is it for us, Messenger of Allah?

After the words of the woman, the Prophet Mubammad looked at the companions who were in the assembly, be said: Do you hear what she is complaining about? Then the Prophet Mubammad turned to Asma' and said: convey to the people who sent you bere, obeying and practicing what Allah is pleased with is balancing all the advantages possessed by men.

In another hadith from Ibn Abbas, the Prophet Muhammad replied: convey to the women when you meet that being loyal to your busband and acknowledging the rights of the busband is the same as the men's fight as you ask. But few of you dutifully do $i t^{15}$

Based on the explanation above, the constraints for career women at Islamic Universities in Kalimantan in

15 Hamka, "Kedudukan Perempuan dalam Islam", Jakarta: PT Citra Serumpun Padi, (1996): 16 
carrying out the household affairs are the negative impacts due to the dual role played by women in the family. From the perspective of maqashid asSyari'ah, household affairs such as taking care of the house, educating and taking care of children are Dharuri (important) matters that demand someone to be responsible. If no one is responsible for the household affairs, it will result in damage to the household order. Abandoned household affairs can trigger conflict between family members, especially between husbands and wives. Therefore, a strategy is needed to minimize this conflict. In addition, the strategy of career women in completing household affairs is sufficient to reduce their burden and guilt when they cannot optimally carry out those affairs.

\section{Strategy of Career Women at}

\section{Islamic Universities in}

\section{Kalimantan in Carrying Out}

Household Obligations from the

Perspective of Maqashid as-

\section{Syari'ah}

Based on the research data, the researchers succeeded in exploring several strategies carried out by career women at Islamic Universities in Kalimantan in carrying out household obligations, namely: (1) caring for underprivileged students to help take care of housework and their tuition fees are paid for that, (2) setting up a household assistant, (3) doing the housework alone by getting up early, sometimes assisted by family or other people, (4) sharing roles and cooperating with the husband.

The strategy that the researchers mean is the efforts made by career women wisely in carrying out and completing household obligations. Based on research data, all career women who become the officials at Islamic Universities in Kalimantan are tied to marriage, so that they have a sense of responsibility for the works in the household. However, when they carry out household obligations, there are several negative constraints such as fatigue and lack of productive time at home, but the constraints they experience can be overcome by making strategies so that household obligations can be resolved properly.

According to the results of research conducted by Nurlaila and Yolanda 
Mohunggo, conflict strategies in the family and work for career women are (1) cooperation between families to help each other, (2) good communication with family members in order to understand the condition, (3) discipline to prepare all the needs of husbands and children at home before leaving for work, and (4) good communication with the husband and involving him to provide input in decisions making. ${ }^{16}$

The strategy carried out by career women at Islamic Universities in Kalimantan is one of the solutions that is quite helpful when they cannot do their housework optimally on their own. Not being optimal or neglecting the housework for career women are due to having demands in the workplace, such as being required for discipline, totality, and loyalty with their job as career women. This condition for career women certainly requires energy that is timeconsuming, exhausting, and minddraining. Therefore, it is natural that they feel tired when they arrive at home so that it is not uncommon for 12 the quality of fulfilling household obligations to be incomplete and not optimal.

The strategy carried out by career women at Islamic Universities in Kalimantan is one of their senses of responsibility as a housewife as well as a woman who is tied to marriage. The existence of a strategy that is carried out is very helpful for the compulsory work in the household which by nature is their responsibility.

According to Utami Munandar, a married woman has a role as a wife, as a mother, and as a housekeeper. These three roles are the main tasks for women who are already married. ${ }^{17}$

According to Nur Aini Latifah, the condition of women in the family is divided into four roles:

First: Woman with the excellent smart and the best rank (the quality woman is a woman who is able and successful in managing the household and achieving a successful career).

Second: A woman who is successful in the domestic area of the household is a woman who is only successful in

\footnotetext{
17 Sanusi. Et.al, "Kiprah Wanita Islam dalam Keluarga, Karir dan Masyarakat", Jakarta: Pustaka Antara PT, Cet. Ke 2 (1996): 113
} 
building a household because she feels less capable in her career.

Third: The type of woman who is good at a career but neglected in household affairs. If so, she is just selfish to pursue a career but her family is not taken care of. The household affairs are considered to hinder her progress.

Fourth: Women who fail in both household and career affairs are unable to achieve success. ${ }^{18}$

Based on the four roles above, career women at Islamic Universities in Kalimantan are classified as the types of women who are successful in their career fields because they become important officials in the Islamic Universities environment where they work and have careers. They have important positions in their workplaces such as serving as Deputy Chancellor, Dean, Head of Institution or Head of Department, and Head of the Study Program. The position held as a career woman is of course very draining the mind, time, and energy. It is not uncommon for work or problems in the workplace to be

18 Titin Fatimah, "Wanita Karir dalam Islam", Jurnal Musawa, Vol. 7, No. 1, Juni (2015): 38 carried home. Hence, naturally, they have problems in carrying out their household obligations due to their fatigue and limitations in playing a dual role.

In the perspective of Maqashid Syari'ab, the strategies carried out by career women at Islamic Universities in Kalimantan in carrying out household obligations are classified in the criteria of Maqashid al-bajizyah. The intent of maqashid al-Hajizyah is the level of importance that must be done, and it will be difficult if it is not done. Another point is that if career women do not have a strategy in managing and completing household obligations, they will be burdened and feel guilty if the housework is neglected.

Taking care of a household for a modern family based on the strategy of the career women at Islamic Universities in Kalimantan, in principle, is no longer the full responsibility of women, but is a joint responsibility in the family. This can be seen from several strategies they have implemented, including preparing household assistants and sharing roles with the husband. According to Utami Munandar, a 
husband who has a modern attitude certainly considers the matters of children's education and household management to be a shared responsibility, even the husband can participate in carrying out these household obligations. ${ }^{19}$

The attitude of a husband who helps his wife in completing household obligations was also exemplified by the Prophet Muhammad. $^{20}$ The example exemplified by the Prophet Muhammad in completing household obligations was included in the hadith from al-Aswad, I once asked Aisyah ra. (Prophet's wife) about the activities of the Prophet Mubammad in his home. Aisyah replied: The Prophet often helps his wife. When the time for prayer arrives the Prophet immediately goes to pray. According to another hadith, Urwah said that Aisyah was once asked about the activities of the Prophet Mubammad in his home. Aisyah replied: The Prophet sews his clothes, patches his sandals, and does what men used to do in their homes.

${ }^{19}$ Ibid, Sanusi. at.al: 116

20 Ibid, Muhammad bin 'Abdullah alHabdan: 14

\section{CONCLUSION}

Based on the research problems, the results of this study can be concluded as obstacles experienced by career women at Islamic universities in Kalimantan in carrying out household obligations are a negative impact for career women who have the status of wives and housewives. Obstacles occur due to their busy work as officials at work, fatigue after arriving home, and the lack of productive time that can be utilized when they get home. According to the perspective of Maqashid as-Shari'ah, the strategy used by career women at Islamic universities in Kalimantan in completing household obligations belongs to the Maqashid al-Hajiyyah level. The point is an important need that will make it difficult for career women if strategies in completing homework are not carried out. Because career women at Islamic universities in Kalimantan have dual responsibilities, namely the demands of career work and the demands of household work. The obligation to carry out household affairs in the perspective of Maqashid as-Shari'ah 
for the families of career women at Islamic universities in Kalimantan is no longer the full responsibility of women. But it has become a shared responsibility in the family, this can be seen from the several strategies they do, including the family preparing a household assistant or asking for the husband's help.

\section{REFERENCES}

Adnan bin Dhaifullah Alu asySyawabikah, Wanita Karier: Profesi Di Ruang Publik Yang Boleh Dan Yang Dilarang Dalam Fiqib Islam, terj: Zulfan, Jakarta: Pustaka Imam AsySyafi'i (2010).

Al-Habdan, Muhammad bin 'Abdullah. Dzulmul Mar-ah, Terj. Yunus, Melawan Kedzaliman Terbadap Wanita, Jakarta: Pustaka Imam Syafi'i, Cet. Pertama (2004).

Al-Qardhawi, Yusuf. Markazul mar'ati fil Hayah al-Islamiyah, terj. Muh. Suri Sudahri A. dan Entin Rani'ah Ramelan, Jakarta, Pustaka al-Kautsar (1996).

Al-Rasyuni, Ahmad. Nadhariyah alMaqashid I'nda al-Imam alSyathibi. Virginia: The Internasional Institute of Islamic Thought (1995).

Depdikbud, Kamus Besar Bahasa Indinesia, Gramedia Pustaka Utama, Jakarta, cet.1, edisi 4,
(2008)

Fatimah, Titin. Wanita Karir dalam Islam, Jurnal Musawa, Vol. 7, No. 1, Juni (2015).

Hamka, Kedudukan Perempuan dalam Islam, Jakarta: PT Citra Serumpun Padi, (1996).

Maleha, Nova Yanti. Pandangan Islam Tentang Piliban Hidup Wanita Karir, An Nisa'a: Jurnal Kajian Gender dan Anak Volume 13, Nomor 01, Juni (2018).

Mawardi, Ahmad Imam. Fiqh Minoritas Figh al-Aqalliyat dan Evolusi Maqashid as-Syari'ah dari Konsep ke Pendekatan. Yogyakarta:LKiS (2000).

Muslim, al-Jaami' as-Shabih al-Muslim Shabih Muslim, Juz. 6, Bairut: Daar al-Afaaq al-Jadidah (t.tt).

Nurlaila dan Yolanda Muhunggo, Persepsi Wanita Karier Terbadap Konflik Pekerjaan dan Keluarga, Jurnal Management Sinergi, Nov 9;1, , (2017).

Sanusi. dkk, Kiprah Wanita Islam dalam Keluarga, Karir dan Masyarakat, Jakarta: Pustaka Antara PT, Cet. Ke 2, (1996).

Umar, Nasaruddin. Fikih Wanita Untuk Semua, Jakarta, cet. 1, PT Serambi Ilmu Semesta (2010). 